\title{
The transformation of supreme values: Evidence from Poland on salvation through civic engagement
}

\author{
Jan Fałkowski ${ }^{1}$ D $\cdot$ Przemysław Kurek ${ }^{1}$
}

Received: 3 September 2019 / Accepted: 15 October 2019 / Published online: 20 November 2019

(C) The Author(s) 2019

\begin{abstract}
Peter Bernholz has described how ideologies and religions with supreme values have used violence to accomplish their goals. We describe the transformation of supreme values through civic engagement and pro-social behavior (dedication to common good, charity, participation in social life) that rejects as unacceptable all forms of violence. Our focus is on Catholicism after the Second Vatican Council, which emphasized the lay faithful's role in the Church's mission of salvation in the world and affirmed categorically that the duty of layperson is to serve other people and society. Using data on Poland, we find that the lay faithful try to fulfil those duties. Religious observance measured by participation in Holy Communion and church attendance correlates positively with civic engagement measured by the number of non-governmental organizations (NGOs).
\end{abstract}

Keywords Supreme values · Catholicism · Laypersons · Civic engagement · NGOs · Poland

JEL Classification Z12 · L31

\section{Introduction}

Bernholz (1993, 1995, 2004, 2006, 2017) has shown that ideologies based on "supreme values" use violence and terrorism to accomplish their goals. Supreme values define lexicographically preferred objectives that are considered by believers to be absolutely true (Bernholz 2004). Adherents of such preferences seek to accomplish the first-ranked one by all possible means. That includes sacrificing the lives of others, in addition to their own. To support his thesis, Bernholz (2017) provides various examples of ideologies based on supreme values that have existed over the centuries, including national socialism in Germany, communism in Russia, and — what is most important for this paper-various organizations resting significantly upon fusions of political and religious authorities.

Jan Fałkowski

jfalkowski@wne.uw.edu.pl

Przemysław Kurek

pkurek@wne.uw.edu.pl

1 University of Warsaw, Warsaw, Poland 
An intriguing question relates to the extent to which the goals prioritized by supreme values can be achieved in a peaceful manner. One option is to reform the ideology in question so that less expansionary aims are laid down and consequently fewer demands are placed on believers. This can be driven either by the economic inefficiencies resulting from a given ideology, in which case the ideology will be undermined on economic grounds, or by a military threat from an opposing ideology (Bernholz 1995). In some instances, however, especially in cases involving religious beliefs, such revisions of ideology may not be feasible. That is because some values brook no compromise. An alternative strategy therefore would be to find means of achieving non-negotiable aims in ways that do not rely on force but are based on peaceful missionary work (Bernholz 2006). The latter option is the focus of this paper. We propose that one way in which religious movements can try to peacefully promote goals identified by their supreme values is to interpret them in a way that imposes on believers pro-social behavior (dedication to common good, charity, participation in social life) as a desirable action and rejects as unacceptable all forms of violence. Achieving such a result requires abandoning the rule that the end justifies the means. Put differently, that interpretation of supreme values assumes that good behavior (enabling achievement of supreme objectives) needs to be distinguished from bad behavior (undermining the accomplishing of those objectives). When believers have separable preferences over their behaviors, such an interpretation of supreme values should have transformative effects on people's decisions and social relations. In particular, when confronted with the choice of whether or not to engage in activities promoting the common good, a believer will always take on those tasks regardless of the other choices he or she makes. That behavioral transformation, in turn, will be consistent with promoting supreme values in a peaceful manner by encouraging believers to contribute to the common good.

Our argument builds on the Roman Catholic Church's growing emphasis (especially in the twentieth century) on the active participation of laypersons in the Church's mission of salvation. While the duty of every individual to proclaim the Gospel has been of key importance for Christians since the very beginning of Christianity, renewed and stronger emphasis was placed on the role of the lay faithful in the Church's apostolate during the Second Vatican Council, which went beyond previous interpretations of the laypeople's responsibilities. What is most important, given our focus, the Council explicitly affirmed that seeking the Kingdom of God requires that the lay faithful live the Christian life always in service to individuals and society, rejecting all that denies and compromises peace. ${ }^{1}$ Such interpretation of the lay faithful's obligations identifies pro-social behavior as desirable action and invites all Christians to achieve the Church's supreme objective through civic engagement. Using data on Poland, we find that laypersons strive to fulfil that instruction: in municipalities that display stronger attachment to the Church (as measured by participation in Holy Communion and church attendance), we observe higher levels of civic engagement as measured by the number of non-governmental organizations NGOs.

\footnotetext{
1 An important aspect in that context, which however goes beyond the limits of the present paper, would be to identify the motivations that drove the Church's encouragement of the lay faithful to work more actively towards the Christian animation of the temporal order and the incentives for laypersons to respond positively to that calling. One potential approach to understanding those issues is offered by interest-group theory and rent-seeking (see for example Ekelund et al. 1996; Ferrero 2002; Hillman 2013).
} 


\section{Religio vinculum societatis}

The importance of the active engagement of laypersons in the mission of the Church has been key since the beginning of Christianity. Numerous examples from the New Testament can serve here as illustrations. ${ }^{2}$ Furthermore, the lay faithful have been strongly encouraged to fulfil their mission by taking upon themselves the task of being peacemakers. ${ }^{3}$ That being said, as Bernholz (2017) argues, supreme values, including the supreme values of Christianity, began to develop their own inherent logic in the hands of later followers. As a result, over the course of Christianity's history, one may point to numerous instances in which seeking goals ranked as supreme values were not pursued in a peaceful manner, but were marked by violence. Yet, especially after the debilitating wars among the different Christian denominations in which none was able to subordinate the others (Bernholz 1995), the Church was faced with the necessity of finding a way to proclaim Christianity's supreme values without resorting to the use of force.

For years, the proclamation of the Church's supreme values was associated mainly with the clergy, both men and women, and their mission to preach the Gospel and win converts. That responsibility, however, changed significantly in the twentieth century when the role of the lay faithful's apostolate, and of the different forms it may take, was pondered and reaffirmed as the official position of the Church during the Second Vatican Council. The change was reflected in, among other examples, two foundational Conciliar documents, Lumen Gentium and Gaudium et Spes, as well as in the Decree on the Apostolate of the Laypeople, Apostolicam Actuositatem, issued on 18 November 1965 by Pope St. Paul VI. The special importance of the laypeople's role was mentioned repeatedly during the pontificate of Pope St. John Paul II and was reflected, for instance, in the 1987 Synod of Bishops and the post-synodal Apostolic Exhortation Christifideles Laici of 30 December 1988. The vocation of the laypeople to actively engage in the Church's apostolate is a matter that has also been frequently raised in the speeches and documents of Pope Francis, as for example in his apostolic exhortation Evangelii Gaudium, given on 24 November 2013.

A clear message can be gleaned from the recognition and promotion of the role of the lay faithful in the Church's mission of salvation: Above all, laypersons should persist in their efforts to participate actively in proclaiming the Gospel, whether within families, at work, or in wider communities (Apostolicam Actuositatem 2; Lumen Gentium 3; Christifideles Laici 17; 59; Gaudium et Spes 43). Importantly, that duty should always be fulfilled as a service to society, based on the virtues of charity, justice, and solidarity with others (Gaudium et Spes 74-76; Christifideles Laici 42). As an important expression of the lay faithful's apostolate, one might observe the various forms of volunteer work, caring for those who are sick and suffering, and efforts directed to ensure the moral dimension of life (Christifideles Laici 41, 51-53; Gaudium et Spes 88). Such activities may, and often should, take on various forms of collective action (Apostolicam Actuositatem 15-22). That is because it expresses the social nature of the person and for this reason leads to a more extensive and incisive effectiveness in work (Christifideles Laici 29). Consequently, to the

\footnotetext{
${ }^{2}$ Go into all the world and preach the gospel to the whole creation (Mark 16:15). For the Kingdom of heaven is like a householder who went out early in the morning to hire laborers for his vineyard. After agreeing with the laborers for a denarius a day, he sent them into his vineyard (Matthew 20:1-2). I am the vine, you are the branches (John 15:5).

3 Blessed are the peacemakers (Matthew 5:9) But I say unto you which hear, love your enemies, do good to them which hate you (Luke 6:27).
} 
extent that laypersons succeed in living in harmony with the Church's teachings, one would expect communities characterized by a stronger commitment to the life of the Church to exhibit higher levels of civic engagement than communities in which the attachment to the Church is weaker.

The postulated relationship between religiosity and civic engagement seems wellgrounded in the studies of the relationship between institutions, religious behavior, social capital, and socioeconomic outcomes. In particular, our argument is consistent with the study by Greeley (1997), who finds that religious structures underlie social capital that supports volunteering both in religious and in secular organizations. ${ }^{4}$ Other studies reporting that religious values and involvement are strongly linked to various civic skills and affect volunteering and charitable contributions include Verba et al. (1995), Putnam (2000), Smidt (2003), Beyerlein and Hip (2006), and Stromsnes (2008). ${ }^{5}$ Our analysis is also closely related to studies showing the important role that religious social capital plays in democratic life and in fostering civic virtues (Smidt 2003; Lam 2006; Woodberry 2012; Bolzendahl et al. 2019). ${ }^{6}$ Given that our focus is on the duties of the lay faithful as marked by the Second Vatican Council, we are also close to other studies that have identified the Council as a turning point in many respects. The literature investigating the changes that have taken place in the Church's political theology can serve as example here (Philpott 2007; Troy 2009; Andersen and Jensen 2019). The consequences of the Council's elevation of the lay faithful's status are also analyzed by Berman et al. (2018). ${ }^{7}$

Our paper contributes to the literature along a number of dimensions. First, most of the available literature investigating the effect of religion on civic engagement relies on data from the United States. The evidence from other geographical contexts is relatively sparse (Kaasa 2013). Our aim therefore is to complement existing studies by focusing on Poland, a country in Central Europe in which the Catholic Church shaped individual and group behavior significantly during the communist dictatorship and the pontificate of the Polish Pope St. John Paul II (Weigel 1992; Żaryn 2003). Poland also provides an excellent context for investigating the role of religion, because Roman Catholicism is so intensively dominant. According to a national census conducted by the Central Statistical Office of Poland, more than $96 \%$ of the adult population identifies as Roman Catholic (GUS 2015). That homogeneity is important because empirical analysis of Poland is unlikely to be confounded by the differences in religions and accompanying supreme values that affect studies of other countries in which religious affiliations are considerably more heterogeneous (Ruiter and De Graaf 2006; Lim and MacGregor 2012; Bolzendahl et al. 2019).

Our study also differs from the extant literature in examining the relationship between church attendance (and participation in Holy Communion) and the number of NGOs. To the best of our knowledge, that relationship has not been subjected to close empirical scrutiny, with the existing studies having looked at other proxies for civic engagement. The Polish context again provides an interesting environment for study. After the collapse of the

\footnotetext{
4 Those connections are obviously not confined to Roman Catholicism. For a clear exposition of the point that religion, in this case Judaism, can serve as a basis for establishing cohesive groups, see Greif (2006).

5 Glaeser et al. (2002), however, argue that social capital accumulation decisions are driven mainly by individual incentives rather than by group membership.

${ }^{6}$ For a more general discussion of the role of Christianity in promoting institutions of freedom, see for example Facchini (2010).

7 Their focus, however, differs from ours and centers on the relationship between the decline in the number of religious vocations (in response to the enhanced status of the lay faithful) and fertility.
} 
communist dictatorship, when the institutional barriers to creating NGOs were removed, such organizations expanded rapidly, rising from approximately 2000 in 1989 to slightly more than 100,000 in 2015 (Teisseyre 2014; Adamiak et al. 2016).

Finally, and what is most important, we differ from existing studies in the way we try to endogenize religious behavior. As is widely acknowledged, identifying the causal impact of religion encounters major hurdles owing to issues arising with respect to measurement error, omitted variable bias, and reverse causality (Iyer 2016). In order to address such concerns, we instrument the attachment to religion at the local level by the shares of streets with names associated with the Church and the number of sacred monuments. We are not aware of any other study that has investigated the effect of religion on fostering civic engagement using an empirical strategy similar to ours. To the best of our knowledge, the use of such data for eliciting the population's values and attitudes has also rarely been used in other applications (the recent study by Oto-Peralias 2018, which uses a similar approach to measure religiosity in Spain, is a notable exception). ${ }^{8}$

Before we move further, an important reservation needs to be mentioned. The argument that has been put forward assumes a causal relationship between the supreme values of Roman Catholicism and civic engagement. However, in our empirical analysis, we work with data on religious observances. Thus-although such observances seem to offer plausible indicators of supreme values being actively upheld by individuals and communitiesour approach is less than perfect. The fact that one attends Mass weekly (or even takes Holy Communion) does not preclude one from having a tenuous connection to the faith. Consequently, the validity of our approach rests to a significant extent on the degree to which religious observance mirrors adherence to the Church's teaching - that is, on something that evades measurability and thus is difficult to assess. That caveat has to be kept in mind when interpreting our empirical results.

\section{Empirical strategy and data}

To gain a better understanding of the relationship between social attachments to the Church and civic engagement, we estimate the following ordinary least squares (OLS) model:

$$
y_{i}=\beta \text { religiosity }_{i}+\gamma X_{i}+\mu_{r}+\vartheta_{j}+\varepsilon_{i},
$$

where our dependent variable is a measure of civic engagement at the municipality level, $i$, defined as the log of the number of NGOs (associations and foundations) per 10,000 municipal inhabitants. Normalizing the number of NGOs by the number of municipal residents ensures that our measure does not simply reflect the fact that more NGOs operate in more populous regions. To create the NGO variable, we rely on 2017 data from the Central Statistical Office of Poland. While that variable captures all types of activities undertaken by NGOs in a municipality, and thus may be considered a good proxy for overall civic engagement, its use carries an important caveat. We are not able to distinguish between different types of NGOs (whether they are religious or secular, charitable or educational, based on paid work or voluntarism, and so on). We therefore cannot say anything about the extent to which the effect of religiosity varies with the type of NGO. That being said, we try to address that issue, at least partly, in an indirect way (see below).

${ }^{8}$ We thank an anonymous referee for drawing our attention to the paper. 


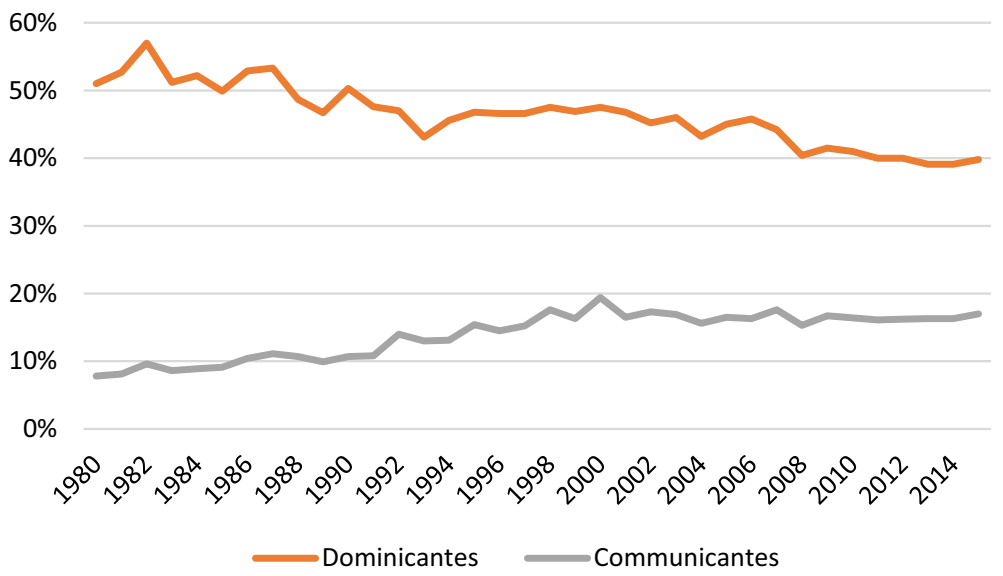

Fig. 1 Church attendance in Poland 1980-2015. Source: Own elaboration based on the data from the Institute for Catholic Church Statistics in Poland

Our key explanatory variable of interest, religiosity ${ }_{i}$, is measured in two alternative ways. On the one hand, we use the (logged) share of Catholics who attended Mass on an ordinary Sunday (dominicantes). ${ }^{9}$ Alternatively, we measure the level of religiosity by the (logged) share of Catholics who participated in Holy Communion (communicantes). Both of the measures are based on data collected by the Institute for Catholic Church Statistics (ISKK) and stem from the practice of the Catholic Church in Poland of counting in each year the number of adherents attending Mass and participating in Holy Communion on one Sunday in autumn. ${ }^{10}$ The use of those two alternative measures allows us to capture differing dimensions of attachment to the Church as reflected in participating in Holy Communion and attending Mass. The data on religiosity refer to 2008 and are the most recent data available to us. Because our dependent variable is measured as of 2017 , the fact that religiosity is measured as of 2008 should mitigate, at least partly, the concern that our relationship in question suffers from reverse causality. ${ }^{11}$

The evolution of church attendance in Poland over time is depicted in Fig. 1. We observe that over the last 35 years, the share of dominicantes in Poland declined from more than $50 \%$ in the 1980 s to approximately $40 \%$ in 2015 . That reduction is less dramatic than one would have predicted based on secularization theory. Furthermore, the decline in the

\footnotetext{
9 The numbers in the denominators exclude children under 7 years of age, the sick, and elderly people who are not obliged to attend Mass. For more details on how these data have been created, see http://iskk.pl/ badania/religijnosc/47-uncategorised/63-dominicantes.

10 The Sunday on which the count is done varies from year to year. The data source assures, however, that it is an ordinary Sunday in autumn (i.e., not overlapping with larger church feasts or other Holy Days).

11 The precise mechanism through which civic engagement may affect the level of religiosity is not clear, though. On the one hand, one can argue that NGOs of strictly religious character can win converts or slow the pace of secularization, implying a positive impact of NGOs on the level of religiosity. But on the other hand, secular activities (which certainly include various forms of civic engagement) can provide a substitute for religious consumption (e.g., Gruber and Hungerman 2008), reduce belief in the institutionalized church (Becker et al. 2017), or disturb the complex balance between social programs provided by the state and by the Church (Huber and Stanig 2011; Gaskins et al. 2013). As such, it can be claimed that people's involvement in secular NGOs may provide an explanation for declines in church attendance.
} 
share of dominicantes took place mainly in the 1980s. An additional decline, although of a more modest nature, can be observed during the 2006-2015 period. In the 1990s and the first half of the 2000s, the share of dominicantes was relatively stable. The share of communicantes over the last 35 years displays an upward trend, increasing from approximately $8-10 \%$ in the 1980 s to $17 \%$ in 2015 . The increase took place mainly in the 1980 s and 1990s. Since the year 2000, the share of people taking Holy Communion has remained relatively stable. While the picture falls outside simple interpretations, what it does suggest is that religiosity in Poland has had the potential to influence large numbers of people. ${ }^{12}$

In order to control for potentially confounding factors that may correlate with both the number of NGOs and the levels of local religiosity, we enter into our model several covariates captured in the vector $X_{i}$. All of those variables were created from information published by the Central Statistical Office of Poland (GUS) and the National Election Commission (PKW). To start with, we control for the level of voter turnout in the local elections that were held in 2010. That is the year closest to the year for which we have data on religiosity. Controlling for the turnout is important, as it may be argued that, given individual non-decisiveness and expressiveness, people exhibiting higher levels of civic engagement may be more likely to vote (Van der Meer and Van Ingen 2009). On the other hand, because elections in Poland are held on Sundays, one may argue that turnout may correlate positively with Mass attendance, since people may travel to polling places after going to a church. Controlling for voter turnout therefore seems to be a natural solution for ensuring that our relationship in question is not driven by that effect.

To further control for the complex linkages between civic engagement, religiosity, and politics, our models always include variables that aim at capturing the distribution of political preferences at the municipality level. Those variables take into account that the Church may directly or indirectly facilitate coalition formation with given political movements or their oppositions and, therefore, influence electoral mobilization (Grzymala-Busse 2013). To address that issue, in our models we control for the outcomes of presidential elections held, depending on the model, either in 2015 or in $2010 .{ }^{13}$ Our focus is on the results obtained by the first six candidates. ${ }^{14}$ As a robustness check on our results, instead of controlling for the outcomes of presidential elections, we enter variables capturing the results for the main political parties in either parliamentary or local elections. ${ }^{15}$ Importantly, regardless of the choice of electoral variables, our findings remain qualitatively the same.

One concern with establishing the relationship between religiosity and civic engagement is that they both may correlate closely with levels of generosity as reflected in charitable giving (Hungerman 2005; Iyer 2016). If that is indeed the case, then the two variables may be spuriously correlated, reflecting the fact that, on the one hand, religious people

\footnotetext{
12 Note that our measure captures mainly people who attend Mass frequently. One may argue, therefore, that the group of people who could potentially be influenced by the Church's teaching is likely to be larger than that depicted in the figure. According to Adamczuk et al. (2013), in 2012, the share of Poles who attended Mass at least once or twice a month amounted to $71.2 \%$.

13 To better control for the initial distribution of political preferences, in some robustness checks we enter the outcomes of the first presidential elections after the collapse of the communist dictatorship, which were held in 1990. Our results are robust against that test.

14 The choice was driven by the fact that we wanted to include the four candidates with the most electoral support as well as two candidates (Marek Jurek and Janusz Korwin-Mikke) who could be regarded as most closely attached to the Church's teaching and to libertarian values, respectively.

15 The data on parliamentary elections refer to either 2015 or 2011 , whereas the data on local elections refer to either 2014 or 2010.
} 
may be more generous, and on the other hand, that NGOs often support themselves on charitable donations. To address that concern, our set of covariates includes collections of money from the public per 10,000 inhabitants of a given municipality in 2014 . That variable should capture, at least partly, the incidence of charitable donations at the local level.

In our regressions we also control for the 2014 shares of population beyond working age (65 and 60 years of age or older for men and women, respectively). That is done in order to control for the potentially confounding influence of old age. On the one hand, older people typically have higher rates of churchgoing. On the other hand, their specific needs (related to social care, recreation, or preventing various forms of exclusion) suit the profile of many Polish NGOs very well. ${ }^{16}$

In addition, our set of covariates includes variables measuring the distance to the regional capital, the log of population density, the log of local government tax revenues, and the logged municipal unemployment rate, all measured as of 2014. The former two variables aim at controlling for the fact that municipalities may differ in their levels of civic engagement and religiosity depending on their degree of urbanization. More specifically, one may assume that both NGOs and secularization processes occur especially in urban centers. The variables measuring tax revenues and unemployment, in turn, aim to capture the heterogeneity in economic conditions, which may also affect both the number of NGOs and church attendance (Iannaccone 1998; McCleary and Barro 2006).

Finally, our model always includes a full set of regional dummies $\mu_{r}$ as well as type of municipality dummies $\vartheta_{j}$. The former set of dummies aims at capturing fixed effects at the county level (powiat). We can thereby control for the time-invariant differences across those administrative units. That control is important, because it can be argued that Poland displays substantial heterogeneity along various dimensions, including heritage from the communist past, historical attachments to the Church, and political preferences (Grossfeld and Zhuravskaya 2015). Including fixed effects at the regional level ensures that our estimates are not driven by such unobserved differences. The dummies capturing municipality type, in turn, aim at further controlling for the differences that can be observed between urban and rural areas. In the model, we enter dummies for both rural municipalities and urban-rural municipalities. The third type, i.e., urban municipalities, acts as a reference group. Including those dummies allows us to control for the fact that church attendance in rural municipalities is typically higher than that observed for urban municipalities. For the last type of municipalities, we also typically observe higher numbers of NGOs.

\section{Results}

The estimates of our OLS regressions are reported in Table 1. The odd columns present the specifications in which the key explanatory variable captures the logged shares of Catholics who attended Mass (dominicantes), whereas the even columns refer to specifications in which the key explanatory variable measures the log of the share of Catholics who participated in Holy Communion (communicantes). Specifications in columns (1) and (2) control only for regional and municipality-type fixed effects. The subsequent columns, in turn, test the robustness of our findings to the inclusion of basic and additional explanatory

16 We thank an anonymous referee for the suggestion. 


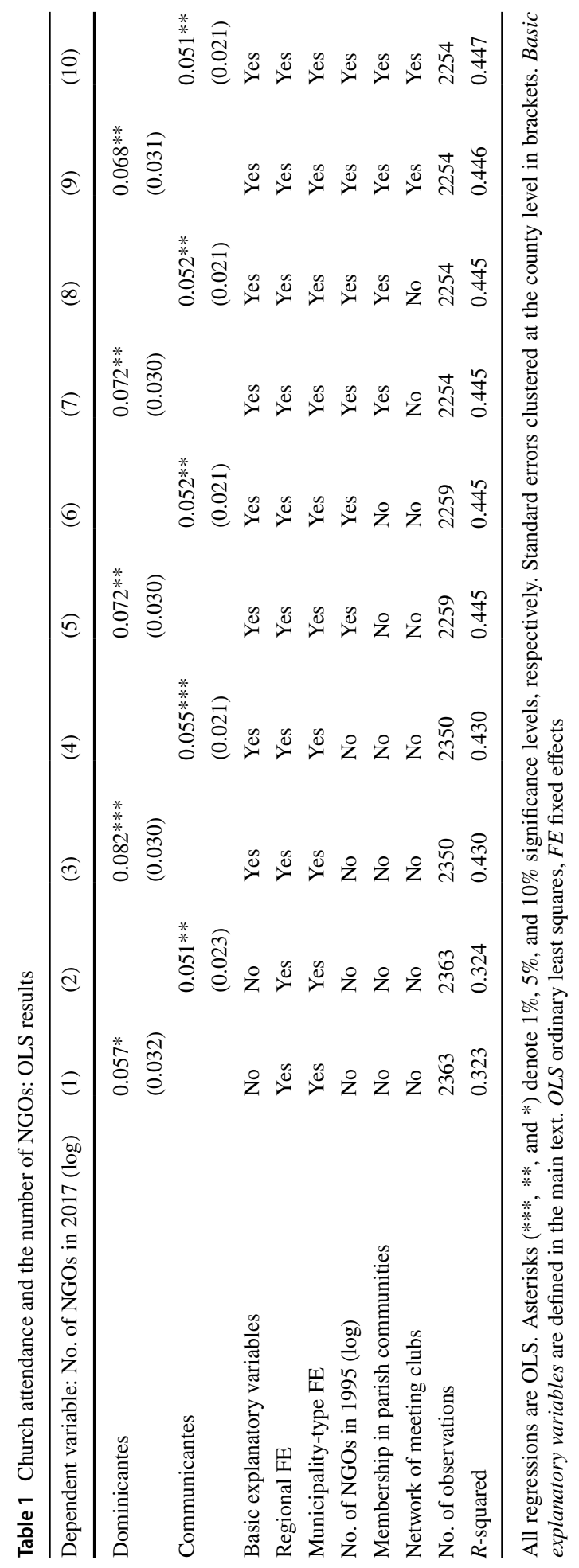


variables. All standard errors are clustered at the county (powiat) level to account for any arbitrary correlation across municipalities from a given county.

As shown, we find that the number of NGOs per $(10,000)$ population correlates positively with the levels of religiosity. That result holds regardless of whether we proxy religiosity with Mass attendance or with participation in Holy Communion. The estimated coefficients in the first two specifications suggest that a $1 \%$ increase in the dominicantes (communicantes) results in an approximately $0.05 \%$ increase in the number of NGOs per 10,000 municipal inhabitants. ${ }^{17}$ Those findings are confirmed in specifications (3) and (4), in which we additionally include the set of basic explanatory variables as discussed earlier. Compared with the estimates of specifications (1) and (2), the magnitudes of the estimated coefficients are now slightly larger and the precision with which they are estimated is slightly higher.

A concern with the foregoing results is that our religiosity measures may correlate with the historical levels of civic engagement. If that were the case, the correlation we find would be spurious. To address that issue, in columns (5) and (6), our set of covariates additionally includes the (logged) number of NGOs per 10,000 population from 1995. That is the earliest year for which the data on NGOs are available to us. The strategy should mitigate concerns that the relationship in question simply reflects the influence of more active civic engagement in the past that happens to correlate positively with our church attendance measures. As reported, the key coefficients of interest remain positive and statistically significant. ${ }^{18}$

As mentioned earlier, our data do not allow us to distinguish between different types of NGOs. Our results therefore do not allow us to propose in greater detail the channels through which the documented effects take place. In columns (7) and (8), we try to address that data issue at least partly by checking whether the result we obtain could be attributed to the effect of religious participation on religious activities, or whether it might also extend to "secular" types of activities. To this end, we use additional data (as of 2008) collected by ISKK on the number of people who are members of various communities associated with parishes (prayer groups, groups reaching out to the poor and excluded, and so on). Based on that information, we constructed a variable equal to the logged number of members of such communities. The new results are fully in line with our earlier findings. As before, the correlation between the number of NGOs and dominicantes (communicantes) is positive and statistically significant at the $5 \%$ level, suggesting that in municipalities in which participation in Mass (Holy Communion) is higher, more NGOs are observed than elsewhere; moreover, that finding should not be attributed to the fact that religious participation increases engagement in parish-based communities.

\footnotetext{
17 Given that the 2008 share of dominicantes amounted to $40.4 \%$ and the share of communicantes amounted to $15.3 \%$, the results imply that to achieve a comparable effect, the increase in dominicantes (in percentage points) should be 2.6 times the increase in communicantes. Put differently, the impact on the number of NGOs of every additional person taking Holy Communion would exceed the impact of every additional person who starts attending Mass.

18 To check more formally whether our religiosity measures can be driven by past levels of civic engagement, we run the model in which our dependent variable is either the share of dominicantes or the share of communicantes and the key independent variable is the logged number of NGOs per 10,000 municipal inhabitants in 1995. Regardless of the covariates we additionally include, the coefficient on lagged NGOs is never statistically significant. That evidence supplies further confidence that our results are not driven by historical correlations between religiosity and civic engagement.
} 
Finally, in columns (9) and (10), we try to further deepen our understanding of the types of NGOs that may be affected by our measures of religiosity. We do so by checking whether our results are not driven by church attendance being positively correlated with NGOs positioning themselves on the right wing of the ideological spectrum. To account for that possibility, our set of covariates now includes a dummy variable based on information about the social movement called Kluby Gazety Polskiej, organized around the weekly journal Gazeta Polska. Kluby Gazety Polskiej is the largest network of meeting clubs in Poland and is clearly associated with the Law and Justice party, the right-wing party that in 2015 won both Poland's presidential and parliamentary elections. The dummy variable (defined as of 2015) is equal to 1 for every municipality in which Kluby Gazety Polskiej held meetings and is equal to zero otherwise. As reported, our results are robust to the inclusion of that variable. Controlling for social movements associated with the political right, we still find that dominicantes (communicantes) have a positive and statistically significant impact on the number of municipal NGOs per 10,000 residents.

\subsection{Instrumental variables approach}

A concern is that our results indicate only correlations and cannot speak to a causal relationship between religiosity and civic engagement. Indeed, cross-sectional studies that aim at investigating the effects of religiosity may be plagued by severe identification problems (Iyer 2016; Becker et al. 2017). To address that concern, we turn to an instrumental variables (IV) approach. As an instrument for current religiosity, we exploit the variation in the (relative) number of streets with names associated with the Catholic Church as well as in the number of sacred monuments. The choice of those instruments is based on the following premises. First, the naming of streets after people or events associated with the Church and the number of sacred monuments may reflect the historical and cultural strength of the Church. As such, the measures might be regarded as good proxies for past levels of religiosity and may thus be important determinants of current attachment to the Church. That supposition is fully confirmed by the first-stage regressions, which show that the two instruments indeed reveal strong effects on current levels of church attendance, especially as measured by Mass attendance (see the bottom of Table 2). Second, no obvious reason can be found to explain why we should expect the two instruments to have a direct influence on current levels of civic engagement, except through their connections with past religiosity. Indeed, it is difficult to come up with a convincing argument as to why people living close to an old church or on a street named after, for example, St. Benedict should feel more inclined to join or establish NGOs just because the church is there or the patron of the street is that one and not another.

That being said, one important concern arises related to our identification assumptions: our instruments may correlate with past levels of civic engagement, and if the latter is persistent over time, our exclusion restriction may not be valid. ${ }^{19}$ While we are not able to unambiguously refute that argument, we believe that three observations weaken it. The first is of a statistical nature and relates to the over-identification test, which checks whether our instruments are indeed uncorrelated with unobservable factors affecting our dependent variable. Our models, especially when we control for additional covariates, pass that test. The second observation, and perhaps the more important, allows us to call into question

19 We thank an anonymous referee for the comment. 


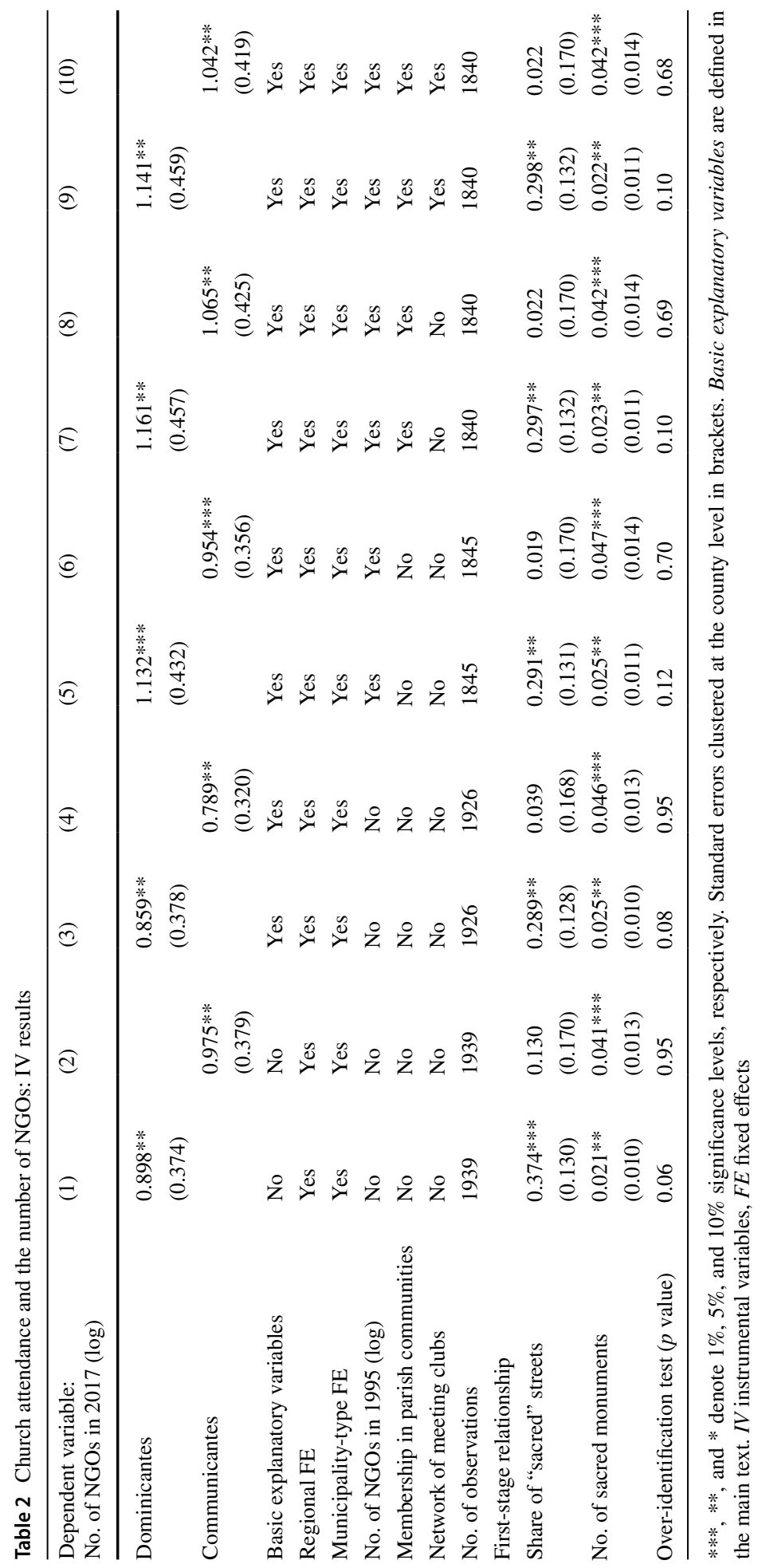


the assumption that civic engagement in Poland can be characterized by its lengthy persistence. It should be noted that for almost 50 years, the communist dictatorship, with all its repressive measures, consciously tried to destroy all forms of cooperation and collective action that were not controlled by the state. Therefore, it seems plausible to assume that the attitude of the communist state, together with the heavy toll taken in World War II, effectively diminished the past reserves of civic engagement. Last but not least, in some specifications applying the IV approach, we do enter the number of NGOs in 1995 among our covariates. Although in an imperfect way, that variable should capture the potential for establishing NGOs in a given municipality after the communist regime was overthrown. In sum, while the caveat regarding our identification strategy should be kept in mind when interpreting our results, we believe that the three points just described mitigate potential concerns that can be raised with respect to it.

Table 2 shows the results of our IV estimations. The columns are analogous to those presented in Table 1. The models include all the variables that were controlled for earlier. The only difference is that they additionally include the total number of streets and the total number of monuments in a given municipality. Both of those variables are included to control for the fact that having ten streets named after a person associated with the Church (or ten sacred monuments) in a municipality with 20 streets (ten monuments in total) differs from having ten such streets (monuments) in a municipality with 5000 streets (200 monuments). The information on street names comes from the Central Statistical Office of Poland and refers to the year 2007 (i.e., 1 year earlier than our religiosity measure). With regard to streets with names associated with the Church, we classified all streets that have in their names the following words: saint, bishop, pope, cardinal, priest, nun, monk, one of the religious orders, or church. The average share of such streets is almost $4 \%$, but in some municipalities it is (much) higher and varies from zero to 100 . The information on monuments comes from the most recent list of national monuments published by the Ministry of Culture and National Heritage. While the list was published in 2016, that is, in the year following the measurement of religiosity, we believe that a 1-year difference should not affect our results, as the information is about historical objects. As sacred monuments, we classified all monuments that were related to churches, parishes, presbyteries, monasteries, and cemeteries. The number of sacred monuments varies from zero to 176 , and the average is 6.7 .

As shown in Table 2, the estimates from the IV models provide strong support for arguing that the levels of religiosity affect the levels of civic engagement in Polish municipalities. Regardless of the other covariates that we include, we find a positive and statistically significant effect of Mass attendance (participation in Holy Communion) on the number of municipal NGOs. That result holds notwithstanding our controlling for the historical number of NGOs, membership in parish-based communities, voter electoral turnout rates, the distribution of political preferences, and other covariates. It should be again noted that our models always include both regional fixed effects and municipality-type fixed effects.

An issue that stands out when our IV estimates are compared with the corresponding OLS estimates is that the former coefficients are much larger than the latter. Indeed, depending on the model, the IV estimates suggest that a $1 \%$ change in our key independent variable results in a $0.8-1 \%$ change in the dependent variable. Subject to the caveat regarding our IV strategy, the results clearly suggest that the relationship in question may seriously suffer from omitted variable bias and/or attenuation bias. In our case, both seem likely to play a role. Regarding the former type of bias, it should be noted that our model does not control for the legacy of Poland's communist dictatorship (except for geographical fixed effects). That omission is important, because it has often been argued that the 
lengthy period of totalitarian rule in Central and Eastern Europe has negatively affected the development of civil society (Fidrmuc and Gerxhani 2008). At the same time, it has been widely acknowledged that the communist state's hostility and repressive attitudes towards its citizens pushed more and more Poles to Catholicism for a space within which to construct the sort of civil society that was otherwise unavailable in the Polish People's Republic (Porter 2011, p. 152). Indeed, the Catholic Church in Poland provided one of the very few opportunities for people to voice their opposition to the dominant order, and offered resources for organizing resistance to communist repression (Froese and Pfaff 2001; Dudek and Gryz 2003; Zieliński 2003; Żaryn 2003). Not accounting for those two effects is likely to produce OLS estimates that are downward-biased. A related but distinct point concerns the opening of market opportunities in 1989. Once the Church ceased to function as a "free social space", religious participation may have declined and various forms of civic engagement may have started to flourish. Again, our OLS estimates do not control for spatial heterogeneity in the extent to which people took advantage of those new opportunities to create a vibrant civil society. Consequently, our coefficient estimates are likely to be too small. Finally, it might be noted that our models fail to control for economic hardships related to the transition process that Poland experienced, especially during the 1990s. The existing literature shows that experiencing economic problems may result in withdrawal from obligations to civil society (non-involvement in public affairs) and more active religious participation, as the latter may provide both material support and emotional benefits (Scheve and Stasavage 2006). Again, the fact that we do not control for those issues suggests that our OLS estimates are likely to be downward-biased.

A second reason why OLS coefficient estimates might be smaller than IV estimates relates to measurement error in the religious participation data. The measure we use is calculated at the municipality level. Originally, however, the data were collected at the parish level (unfortunately, we do not have access to those data). The problem with the aggregate numbers is that not all parishes reported on church attendance. Furthermore, one may assume that the numbers in the denominator of the share of dominicantes (communicantes) might have sometimes been misreported. ${ }^{20}$ Misreporting, in turn, will lead to an attenuation bias, resulting in the coefficients estimated by OLS again being smaller than what we would observe in reality.

\section{Conclusions}

The results we have presented suggest that in the Polish context, religiosity exerted a positive impact on civic engagement. To the extent that religious observance can be considered a useful approximation of how Catholicism's supreme values (fulfilling the mission of salvation) are being pursued in the daily lives of individuals and communities, our findings show that involvement in civic activities can provide a channel through which supreme values associated with religion are propagated in a peaceful manner. Yet, our results raise several important questions.

The first concerns the conditions under which supreme values can be effectively transmitted through civic engagement. Bernholz (2017) suggests that what might be crucial in

\footnotetext{
${ }^{20}$ Note that, while in the numerator we have the precise numbers of people attending Mass (taking Holy Communion), in the denominator we have the numbers of Catholics who are obliged to participate in Mass. The latter number, especially in larger parishes, is often estimated and thus likely to be misreported.
} 
that respect is the role of charismatic leaders who guide believers regarding their supreme values. Alternatively, the impact of religiosity could be generated through private and social learning, so that non-religious people follow the examples of the lay faithful. It seems that in our case, both of those mechanisms are likely to have been in play. On the one hand, the existing literature documents the enormous influence that the Polish Catholic Church and its leaders (Pope St. John Paul II, Cardinal Stefan Wyszyński) had on social, cultural, and political life in Poland during the second half of the twentieth century (Huntington 1991; Weigel 1992; Dudek and Gryz 2003; Żaryn 2003). The proliferation of religious movements and associations in the 1990s (Petrowa-Wasilewicz 2000; Zieliński 2003) can serve as an illustration. On the other hand, our results suggest that the effect of religiosity seems to be broad (not limited to religious activities) and thus might have spilled over to non-religious people either through personal networks or by observation.

Another point concerns the unique context of our study. ${ }^{21}$ More specifically, it is not certain that a similar strategy for promoting religious supreme values through civic engagement could be expected in a context without the Church's prominent role in animating and sustaining cooperation between people, or in one characterized by religiously motivated terrorism. One might also wonder whether similar scenarios can evolve with religions other than Roman Catholicism. Finally, religious participation, the focus of this paper, is only one dimension of religiosity. We cannot say whether other aspects of religiosity (belief or belonging) also matter for the relationship we have studied. We do hope, however, that our findings can move the debate at least a little further regarding the effects that religion, and the supreme values it propagates, has on individual and group behavior.

Acknowledgements We are indebted to Arye Hillman for his advice and guidance. We would also like to thank the editor, two anonymous referees, Christian Bjornskov, Daryna Grechyna, ks. Wojciech Sadłoń, Philip Steele, Robert Stępisiewicz, Heinrich Ursprung, and seminar and conference participants in Warsaw, Chęciny, and Pontresina for their comments and suggestions, and Maja Pieńkos for her excellent research assistance. Financial support from the Polish National Science Centre (Grant No. 2017/25/B/HS4/01072) is gratefully acknowledged.

Open Access This article is distributed under the terms of the Creative Commons Attribution 4.0 International License (http://creativecommons.org/licenses/by/4.0/), which permits unrestricted use, distribution, and reproduction in any medium, provided you give appropriate credit to the original author(s) and the source, provide a link to the Creative Commons license, and indicate if changes were made.

\section{References}

Adamczuk, L., Firlit, E., \& Zdaniewicz, W. (2013). Postawy społeczno-religijne Polaków 1991-2012. Warszawa: ISKK.

Adamiak, P., Charycka, B., \& Gumkowska, M. (2016). Kondycja sektora organizacji pozarzqdowych w Polsce 2015: Raport z badań. Warszawa: Stowarzyszenie Klon/Jawor.

Andersen, T. B., \& Jensen, P. S. (2019). Preaching democracy: The Second Vatican Council and the third wave. Journal of Comparative Economics, 47(3), 525-540.

Becker, S. O., Nagler, M., \& Woessmann, L. (2017). Education and religious participation: City-level evidence from Germany's secularization period 1890-1930. Journal of Economic Growth, 22(3), 273-311.

\footnotetext{
21 Note that countries with similar conditions for religious supply and demand can end up in different equilibria as regards religious markets (Poutvaara and Wagener 2010). We thank an anonymous referee for raising this point.
} 
Berman, E., Iannaccone, L. R., \& Ragusa, G. (2018). From empty pews to empty cradles: Fertility decline among European Catholics. Journal of Demographic Economics, 87, 149-187.

Bernholz, P. (1993). Necessary conditions for totalitarianism. In G. Radnitzky \& H. Bouillon (Eds.), Government: Servant or master (pp. 267-312). Amsterdam and Atlanta: Rodopi.

Bernholz, P. (1995). Supreme values, tolerance and the constitution of liberty. In G. Radnitzky \& H. Bouillon (Eds.), Values and social order (Vol. 1, pp. 235-250). Aldershot and Brookfield: Avebury.

Bernholz, P. (2004). Supreme values and the basis for terror. European Journal of Political Economy, 20, 317-333.

Bernholz, P. (2006). International political system, supreme values and terrorism. Public Choice, 128, 221-231.

Bernholz, P. (2017). Totalitarianism, terrorism and supreme values: History and theory. Cham: Springer.

Beyerlein, K., \& Hip, J. R. (2006). From pews to participation: The effect of congregation activity and context on bridging civic engagement. Social Problems, 53(1), 97-117.

Bolzendahl, C., Schnabel, L., \& Sagi, R. (2019). Religion and democratic citizenship: A multilevel examination. Politics and Religion. https://doi.org/10.1017/S1755048319000087.

Dudek, A., \& Gryz, R. (2003). Komuniści a Kościót w Polsce (1945-1989). Kraków: Wydawnictwo Znak.

Ekelund, R. B., Jr., Hebert, R. F., Tollison, R. D., Anderson, G., \& Davidson, A. (1996). Sacred trust: The medieval Church as an economic firm. London: Oxford University Press.

Facchini, F. (2010). Religion, law and development: Islam and Christianity-why is it in Occident and not in the Orient that man invented the institutions of freedom? European Journal of Law and Economics, 29, 103-129.

Ferrero, M. (2002). Competition for sainthood and the millennial Church. Kyklos, 55, 335-360.

Fidrmuc, J., \& Gerxhani, K. (2008). Mind the gap! Social capital, east and west. Journal of Comparative Economics, 36, 264-286.

Froese, P., \& Pfaff, S. (2001). Replete and desolate markets: Poland, East Germany and the new religious paradigm. Social Forces, 80(2), 481-507.

Gaskins, B., Golder, M., \& Siegel, D. A. (2013). Religious participation and economic conservatism. American Journal of Political Science, 57(4), 823-840.

Glaeser, E. L., Laibson, D., \& Sacerdote, B. (2002). An economic approach to social capital. Economic Journal, 112(438), F437-F458.

Greeley, A. (1997). Coleman revisited: Religious structures as a source of social capital. American Behavioral Scientist, 40(5), 587-594.

Greif, A. (2006). Institutions and the paths to the modern economy. New York: Cambridge University Press.

Grossfeld, I., \& Zhuravskaya, E. (2015). Cultural vs. economic legacies of empires: Evidence from the partition of Poland. Journal of Comparative Economics, 43, 55-75.

Gruber, J., \& Hungerman, D. M. (2008). The Church versus the mall: What happens when religion faces increased secular competition. Quarterly Journal of Economics, 123(2), 831-862.

Grzymala-Busse, A. (2013). Why there is (almost) no Christian Democracy in post-communist Europe. Party Politics, 19(2), 319-342.

GUS. (2015). Struktura narodowo-etniczna, językowa i wyznaniowa ludności Polski. Narodowy Spis Powszechny Ludności i Mieszkań 2011. Warszawa: Zakład Wydawnictw Statystycznych.

Hillman, A. (2013). Rent seeking. In M. Reksulak, L. Razzolini, \& W. F. Shughart II (Eds.), The Elgar companion to public choice (2nd ed., pp. 307-330). Cheltenham: Edward Elgar.

Huber, J. D., \& Stanig, P. (2011). Church-state separation and redistribution. Journal of Public Economics, 95(7-8), 828-836.

Hungerman, D. M. (2005). Are Church and state substitutes? Evidence from the 1996 welfare reform. Journal of Public Economics, 89(11-12), 2245-2267.

Huntington, S. P. (1991). The third wave: Democratization in the late twentieth century. Norman, OK: University of Oklahoma Press.

Iannaccone, L. R. (1998). Introduction to the economics of religion. Journal of Economic Literature, 36(3), 1465-1495.

Iyer, S. (2016). The new economics of religion. Journal of Economic Literature, 54(2), 395-441.

Kaasa, A. (2013). Religion and social capital: Evidence from European countries. International Review of Sociology, 23(3), 578-596.

Lam, P.-Y. (2006). Religion and civic culture: A cross-national study of voluntary association membership. Journal for the Scientific Study of Religion, 45(2), 177-193.

Lim, C., \& MacGregor, C. A. (2012). Religion and volunteering in context: Disentangling the contextual effects of religion on voluntary behavior. American Sociological Review, 77(5), 747-779. 
McCleary, R. M., \& Barro, R. J. (2006). Religion and economy. Journal of Economic Perspectives, 20(2), 49-72.

Oto-Peralias, D. (2018). What do street names tell us? The 'city-text' as socio-cultural data. Journal of Economic Geography, 18, 187-211.

Petrowa-Wasilewicz, A. (2000). Leksykon ruchów i stowarzyszeń w Kościele. Warszawa: KAI.

Philpott, D. (2007). Explaining the political ambivalence of religion. American Political Science Review, 101(3), 505-525.

Porter, B. (2011). Faith and fatherland: Catholicism, modernity and Poland. New York: Oxford University Press.

Poutvaara, P., \& Wagener, A. (2010). The invisible hand plays dice: Multiple equilibria in sects markets. Public Choice, 145, 483-502.

Putnam, R. D. (2000). Bowling Alone: The Collapse and Revival of American Community. New York: Simon and Schuster.

Ruiter, S., \& De Graaf, N. D. (2006). National context, religiosity, and volunteering: Results from 53 countries. American Sociological Review, 71(2), 191-210.

Scheve, K., \& Stasavage, J. (2006). Religion and preferences for social insurance. Quarterly Journal of Political Science, 1, 255-286.

Smidt, C. (Ed.). (2003). Religion as social capital: Producing the common good. Waco: Baylor University Press.

Stromsnes, K. (2008). The importance of church attendance and membership of religious voluntary organizations for the formation of social capital. Social Compass, 55(4), 478-496.

Teisseyre, P. (2014). Jak rozwijał się sektor? 3 najważniejsze zmiany. https://publicystyka.ngo.pl/jak-rozwi jal-sie-sektor-3-najwazniejsze-zmiany. Retrieved on May 15, 2019.

Troy, J. (2009). 'Catholic waves' of democratization? Roman Catholicism and its potential for democratization. Democratization, 16(6), 1093-1114.

Van der Meer, T., \& Van Ingen, E. (2009). Schools of democracy? Disentangling the relationship between civic participation and political action in 17 European countries. European Journal of Political Research, 48(2), 281-308.

Verba, S., Schlozman, K. L., \& Brady, H. E. (1995). Voice and equality: Civic volunteerism in American politics. Cambridge: Harvard University Press.

Weigel, G. (1992). The final revolution: The resistance Church and the collapse of communism. Oxford: Oxford University Press.

Woodberry, R. D. (2012). The missionary roots of liberal democracy. American Political Science Review, 106(2), 244-274.

Zieliński, Z. (2003). Kościót w Polsce 1944-2002. Radom: Polskie Wydawnictwo Encyklopedyczne.

Żaryn, J. (2003). Dzieje Kościota katolickiego w Polsce (1944-1989). Warszawa: Wydawnictwo Neriton.

Publisher's Note Springer Nature remains neutral with regard to jurisdictional claims in published maps and institutional affiliations. 